\begin{abstract}
"Mircea cel Batran" Naval Academy Scientific Bulletin, Volume XX - 2017 - Issue 1
Published by "Mircea cel Batran" Naval Academy Press, Romania // The journal is indexed in: PROQUEST I

DOAJ / DRJI / JOURNAL INDEX / I2OR / SCIENCE LIBRARY INDEX / Google Scholar / Crossref / Academic Keys I ROAD Open Access I OAJI / Academic Resources / Scientific Indexing Services / SCIPIO / JIFACTOR
\end{abstract}

\title{
CONSIDERATIONS ON THE SHIP'S HYDRODYNAMIC FIELD
}

\author{
Gheorghe ICHIMOAEI ${ }^{1}$ \\ Octavian TĂRĂBUŢÄ ${ }^{2}$ \\ Cătălin CLINCI ${ }^{3}$ \\ Beazit ALI" \\ ${ }^{1}$ Lecturer PhD., "Mircea cel Batran" Naval Academy \\ ${ }^{2}$ Assistant professor PhD., "Mircea cel Batran" Naval Academy \\ ${ }^{3}$ Lecturer PhD., "Mircea cel Batran" Naval Academy \\ ${ }^{4}$ Professor PhD., "Mircea cel Batran" Naval Academy
}

Abstract: In this paper we studied the possibility to compute ship's hydrodynamic field. The level of ship's hydrodynamic field is depending by ship's overall dimensions and speed. The hydrodynamic field values are important, because are used to determining the speed with which you can navigate safe in an area where depth and sensitivity mines are known.

Keywords: hydrodynamic field, marine mines, explosion, sources, flows

Navy and commercial ships are characterized by physical fields (magnetic, electric, acoustic and hydrodynamic) generated by ship's shape, materials used in construction, operation of different kind of machinery, installations and equipment fitted on board and ship's movement in the earth's magnetic field.

For the MCM (Mine Counter Measures) vessels like mine hunters and mine sweepers, the magnetic field values are important, because are used to determining the speed with which you can navigate safe in an area where depth and sensitivity mines are known.

Ship's acoustic field cover a very large spectrum of frequencies from infrasound to ultrasound. The level of the acoustic field gave submariners the possibility to detect a surface ship which is underway or could initiate the explosion of acoustic mines.

The level of ship's hydrodynamic field is depending by ship's overall dimensions and speed.

\section{The link between pressure and perturbation's speed}

When a body is moving in to a liquid, in surrounding space the perturbation's speed will appears. According with Bernoulli equation, speed changing will produce pressure variation. General movement of a fluid could be decomposed as:

- a translational movement with speed $\overline{v_{0}}$;

- a rotational movement with angular velocity $\varpi$;

- a deformation movement with speed given by $\overline{v^{\prime \prime}}=\operatorname{grad} \Phi$.

So, the speed of fluid could be written as:

$$
\bar{v}=\overline{v_{0}}+\overline{\varpi \times \rho}+\operatorname{grad} \Phi \text {. }
$$

In order to estimate the level of ship's hydrodynamic field, we made the following assumptions:

- the water stream is considered potential (in the water stream particles do not rotate);

- Only pressure and volume forces will act on the ship's hull.

We consider a body of some form positioned in a Oxzy system of axes, which is moving through liquid with speed $\mathrm{v}_{0}\left(\overline{v_{0}} / / \mathrm{Ox}\right)$.

Speed's potential in a point $C(x, z, y)$, near to the body, could be written as:

$$
\Phi(x, z, y)=v_{0} \cdot x+\varphi(x, z, y)
$$

where:

$v_{0} \cdot x=$ Speed's potential for direct stream;

$$
\varphi(x, z, y)=\quad \text { Perturbation speed's }
$$

potential produced by the body.

The components of speed on each axle of reference frame could be written as:

$$
\begin{aligned}
& v_{x}=\frac{\partial \Phi}{\partial x}=v_{0}+\frac{\partial \varphi}{\partial x}=v_{0}+w_{x} \\
& v_{y}=\frac{\partial \Phi}{\partial y}=w_{y} ; \\
& v_{z}=\frac{\partial \Phi}{\partial z}=w_{z} .
\end{aligned}
$$

Based on perturbation speed's potential $\varphi(x, y, z)$, we could compute components of speed on each axle of reference frame, which give the value of hydrodynamic field. We consider two points (figure 1): one is located to infinity and speed of stream is $v_{0}$ and pressure is $p_{0}$ and the other one is located on $C(x, z, y)$ where speed is $v$ and pressure $p$. For these points, the Bernoulli equation is: 
"Mircea cel Batran" Naval Academy Scientific Bulletin, Volume XX - 2017 - Issue 1

Published by "Mircea cel Batran" Naval Academy Press, Romania /I The journal is indexed in: PROQUEST I

DOAJ / DRJI / JOURNAL INDEX / I2OR / SCIENCE LIBRARY INDEX / Google Scholar / Crossref / Academic Keys I ROAD Open Access / OAJI / Academic Resources / Scientific Indexing Services / SCIPIO / JIFACTOR

$$
\begin{aligned}
& \frac{\rho v_{0}^{2}}{2}+p_{0}=\frac{\rho v^{2}}{2}+p, \\
& \text { where } v^{2}=v_{x}^{2}+v_{y}^{2}+v_{z}^{2} .
\end{aligned}
$$

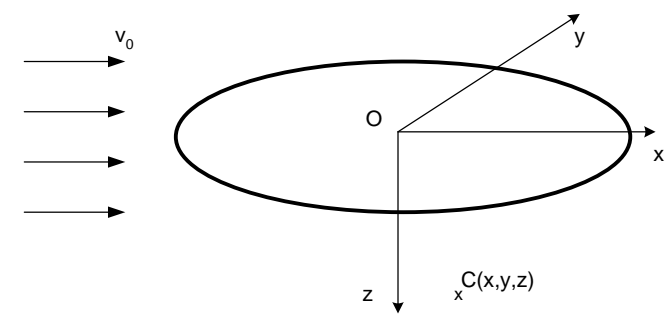

Figure 1. The positioning of ship's body in to the stream

Because $w_{x}^{2}=w_{y}^{2}=w_{z}^{2}=0$, we can write:

$$
v^{2}=v_{0}^{2}+2 \cdot v_{0} \cdot w_{x} \text {. }
$$

In this case, the Bernoulli equation is:

$$
\begin{aligned}
& \mathrm{p}-\mathrm{p}_{0}=-\rho \cdot v_{0} \cdot w_{x} ; \\
& \Delta p=-\rho \cdot v_{0} \cdot w_{x} .
\end{aligned}
$$

Equation (6) represents the link between pressure and perturbation's speed.

\section{The intensity of the sources and flows}

When a ship is moving, water particles acquire a moving speed which decrease as the remoteness of the ship's hull, which makes in the surrounding space at each point the pressure to have different values.

Ship hydrodynamic field is, by definition, the space around the ship, below the waterline that identifies a variation of hydrostatic pressure due to the presence and movement of the ship.

Hydrodynamic field is one of the main characteristic of the ship.

We considered a reference frame Oxyz, linked to the ship, with $O$ point at the intersection between waterline plane, longitudinal plane and diametrical plane of the ship. In the space below the ship (Figure 2), we intend to compute the ships hydrodynamic field in point $C(x, y z)$, when ship is moving with $v_{0}$ speed.

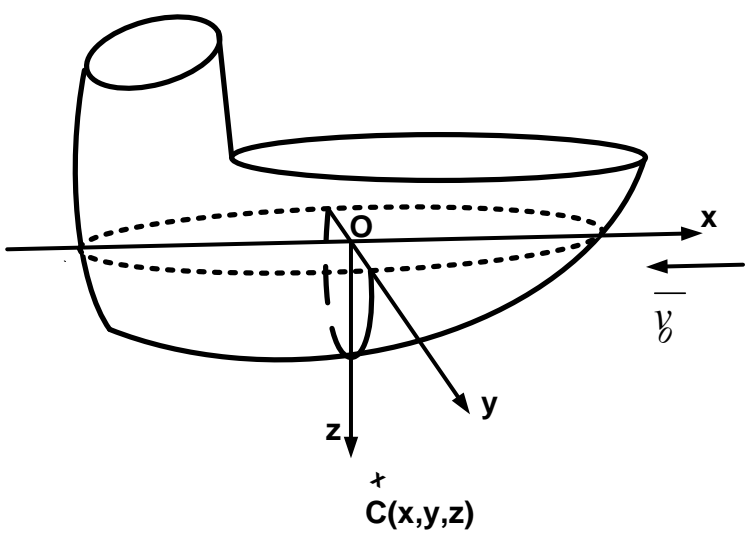

Figure 2. Reference frame linked to the ship

For this reason, we have to calculate in point mentioned before, speed potential $\Phi(x, y, z)$, solving the following Laplace equation:

$$
\frac{d^{2} \Phi}{d x^{2}}+\frac{d^{2} \Phi}{d y^{2}}+\frac{d^{2} \Phi}{d z^{2}}=0
$$

Boundary conditions on the surface of the hull are that the ship's side do not soak, which means that the fluid velocity vector at the surface side of the vessel is guided by the tangent of the hull.

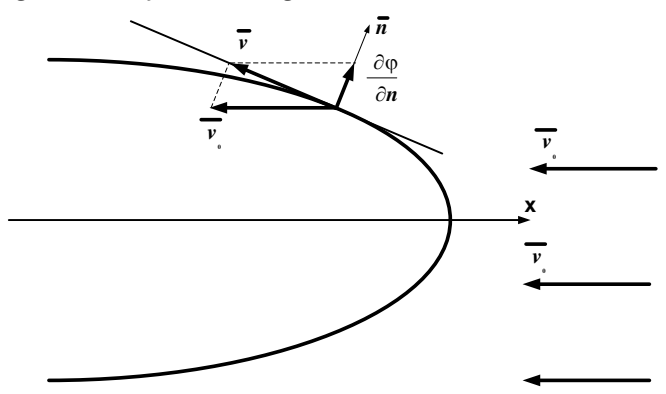

Figure 3 Water flow velocity components in the hull

Let $\bar{n}$ perpendicular to the hull. According with figure 3 , the incident component of flow velocity is:

$$
\frac{\partial \varphi}{\partial n}=v_{n}=-v_{0} \cdot \cos (n, x)
$$

The partial derivative of the full potential $\Phi(x, y, z)$ is 0 , so $\frac{\partial \Phi}{\partial n}=0$.

Boundary conditions on the hull are:

$$
\frac{\partial \Phi}{\partial n}=0 \text { or } \frac{\partial \varphi}{\partial n}=-v_{0} \cdot \cos (n, x)(9)
$$

Solving the problem for the boundary conditions at the surface, considering the waves formed by the movement of the ship, it is mathematically complicated and is not subject of our paper.

Therefore, the method of calculation shown next is fair only for lower speeds, when formed waves 
"Mircea cel Batran" Naval Academy Scientific Bulletin, Volume XX - 2017 - Issue 1

Published by "Mircea cel Batran" Naval Academy Press, Romania /I The journal is indexed in: PROQUEST I DOAJ / DRJI / JOURNAL INDEX / I2OR / SCIENCE LIBRARY INDEX / Google Scholar / Crossref / Academic Keys I ROAD Open Access / OAJI / Academic Resources / Scientific Indexing Services / SCIPIO / JIFACTOR

practically have no influence on the ship's hydrodynamic field.

This value of speed must check the Froude number:

$$
F r=\frac{v_{0}}{\sqrt{g \cdot L}} \leq 0,3,
$$

where: $v_{0}-$ ship speed $[\mathrm{m} / \mathrm{s}]$;

$\mathrm{g}$ - Acceleration of gravity $\left[\mathrm{m} / \mathrm{s}^{2}\right]$;

$\mathrm{L}$ - Ship length $[\mathrm{m}]$.

During the movement the ship remove liquid particles giving them a certain speed. So, at the bow is permanently displaces a volume of water and in the aft water is absorbed. This presentation of the water flow along the hull was written as boundary conditions $\frac{\partial \varphi}{\partial n}=-v_{0} \cdot \cos (n, x)$ and could be completed if we choose the sources and flows system.

The sources are called those streams which continuously goes out at a point in the radial direction and current flow are known those which are permanently going in a point in the radial direction.

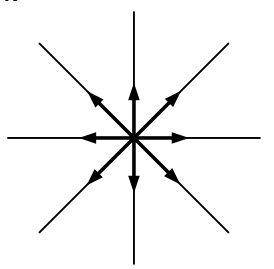

a) Source

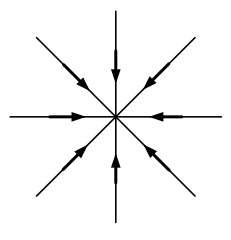

b)Flow
Figure 4. Representations of streams

Regarding to ship hull, we can consider that the bow is a source and the aft is a flow.

We will make two cutoff views on the ship's bow, on diametrical plane, $S_{n}$ şi $S_{n+1}$ (see figure 5), distance between sections is $\Delta x$. Length of the ship between sections is $\Delta I$ and $\Delta r$ is sections rays difference.
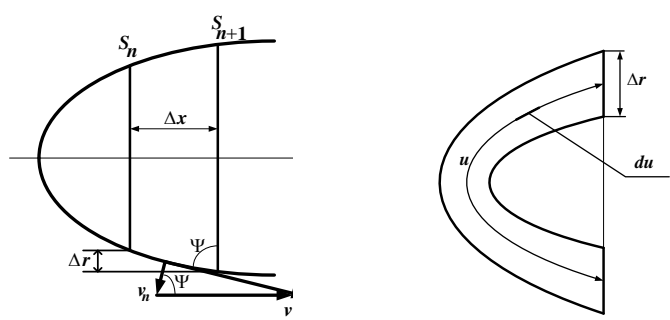

a) up view

b) frontal view

Figure 5. Bow section

Based on figure 5, we can wright:

$$
\begin{aligned}
& v_{n}=v_{0} \cdot \cos \psi ; \\
& \cos \psi=\frac{\Delta r}{\Delta l} ; \\
& v_{n}=v_{0} \cdot \frac{\Delta r}{\Delta l} .
\end{aligned}
$$

Let $u$ - medium perimeter of the shell sector between sections mentioned before, then surface of elementary shell sector is $\Delta r \cdot \Delta u$.

Elementary flow for the shell sector took into consideration will be:

$$
\Delta Q=\int_{0}^{u} v_{n} d A=\int_{0}^{u} v_{n} \Delta l d u,
$$

We can write:

$$
\Delta Q=v_{0} \cdot \Delta r \cdot u
$$

where $u \cdot \Delta r=S_{n+1}-S_{n}=\Delta S$.

As a result:

$$
\Delta Q=v_{0} \cdot \Delta S
$$

Because sources (and flow) acts over the entire length of the vessel, the value of source intensity is

$$
q=\lim _{\Delta x \rightarrow 0} \frac{\Delta Q}{\Delta x}=\frac{d Q}{d x}=v_{0} \frac{d S(x)}{d x}
$$

The $S(x)$ function has values for each type of ship and is called ribs curvature. In figure 6 you can see some values of $S(x)$ function:

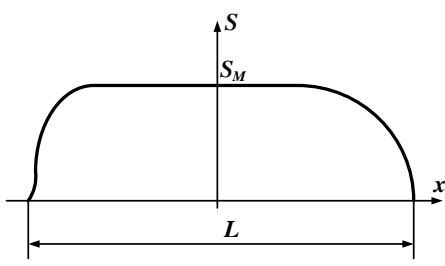

a) Bulk carrier ship

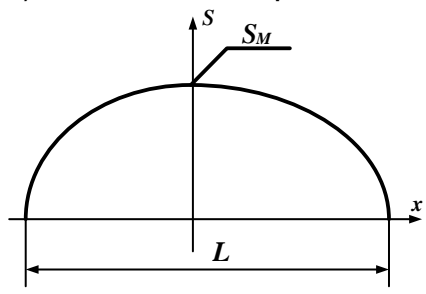

b) Destroyer

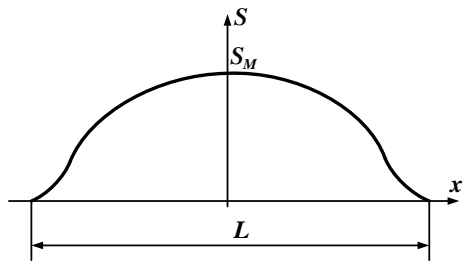


"Mircea cel Batran" Naval Academy Scientific Bulletin, Volume XX - 2017 - Issue 1

Published by "Mircea cel Batran" Naval Academy Press, Romania // The journal is indexed in: PROQUEST I DOAJ / DRJI / JOURNAL INDEX / I2OR / SCIENCE LIBRARY INDEX / Google Scholar / Crossref / Academic Keys I ROAD Open Access / OAJI / Academic Resources / Scientific Indexing Services / SCIPIO / JIFACTOR

c) Submarine

Figure 6. Values for $S(x)$ function vs. ship

type

Surface (in waterline plane) between $S(x)$ function and Ox axis represents ship displacement, which is given by:

$$
\Delta=\int_{-\frac{L}{2}}^{+\frac{L}{2}} S(x) d x
$$

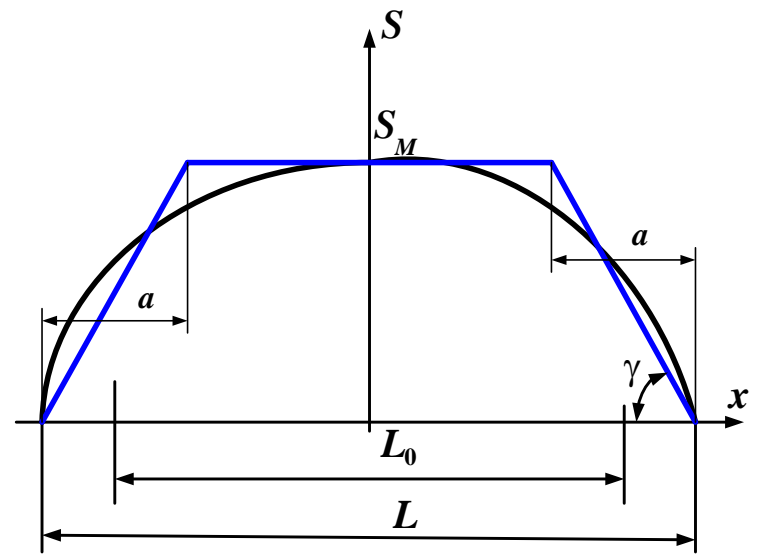

Figure 7. Ribs curvature

On expedite computations the ribs curvature could be approximated by an isosceles trapezoid, see figure 7 . The trapezoid dimensions (height, length and surface) should be the same with ribs curvature. In figure 7 we made the following notations:

a, length of sharp section of ship;

$\mathrm{L}_{0}$, distance between centers of sharped sections of ship;

$S_{M}$, surface of midship frame;

$L$, length of waterline.

The length of sharped section is:

$a=L-L_{0}$

The ship displacement could be compute

with:

$$
\begin{aligned}
\Delta=\int_{-\frac{L}{2}}^{+\frac{L}{2}} S(x) d x= & L_{0} \cdot S_{M}=L \cdot B \cdot T \cdot \delta_{\Delta} \\
\text { where: } & \text { B }- \text { ship width; } \\
& \text { T }- \text { ship draft; } \\
& \delta_{\Delta}-\text { hull volume coefficient. }
\end{aligned}
$$

The surface of midship frame is:

$$
S_{M}=T \cdot B \cdot \beta \text {, }
$$

Where $\beta$ is volume coefficient of midship frame.

From displacement equation we have:

$$
L_{0} T B \beta=L B T \delta_{\Delta},
$$

where

$$
L_{0}=L \frac{\delta_{\Delta}}{\beta},
$$

and:

$a=L-L_{0}=L\left(1-\frac{\delta_{\Delta}}{\beta}\right)$

Ratio $\frac{\delta_{\Delta}}{\beta}$ has the following values:

$\frac{\delta_{\Delta}}{\beta}=0,6 \div 0,7$, for navy ships;

$\frac{\delta_{\Delta}}{\beta}=0,7 \div 0,8$, for commercial ships.

According with figure $7, q=v_{0} \frac{d S(x)}{d x}$,

and

$$
\frac{d S(x)}{d x}=\operatorname{tg} \gamma=\frac{S_{M}}{a}=\text { const }
$$

In conclusion:

Source intensity is:

$q=v_{0} \cdot \frac{S_{M}}{a}$;

Flow intensity is:

$$
q=-v_{0} \cdot \frac{S_{M}}{a} \text {. }
$$

\section{Computation of ship's hydrodynamic field}

In order to compute the hydrodynamic field of the ship, vessel is represented as having disposed linear sources on the sharp section of bow, and flows on the sharp section of stern. In point $C(x, y, z)$ we compute the perturbation velocity $\mathrm{w}_{\mathrm{x}}$. Elementary flow for $\Delta x$ sector will be:

$\Delta Q=q_{s} \cdot \Delta x$

$$
\text { Because } w_{s}=\frac{Q}{\frac{4 \pi R^{2}}{2}} \text {. }
$$

the elementary perturbation velocity is:

$$
\Delta w_{s}=\frac{\Delta Q}{2 \pi R^{2}}=\frac{q_{s} \cdot \Delta x}{2 \pi R^{2}} .
$$


"Mircea cel Batran" Naval Academy Scientific Bulletin, Volume XX - 2017 - Issue 1

Published by "Mircea cel Batran" Naval Academy Press, Romania /I The journal is indexed in: PROQUEST I DOAJ / DRJI / JOURNAL INDEX / I2OR / SCIENCE LIBRARY INDEX / Google Scholar / Crossref / Academic Keys I ROAD Open Access / OAJI / Academic Resources / Scientific Indexing Services / SCIPIO / JIFACTOR

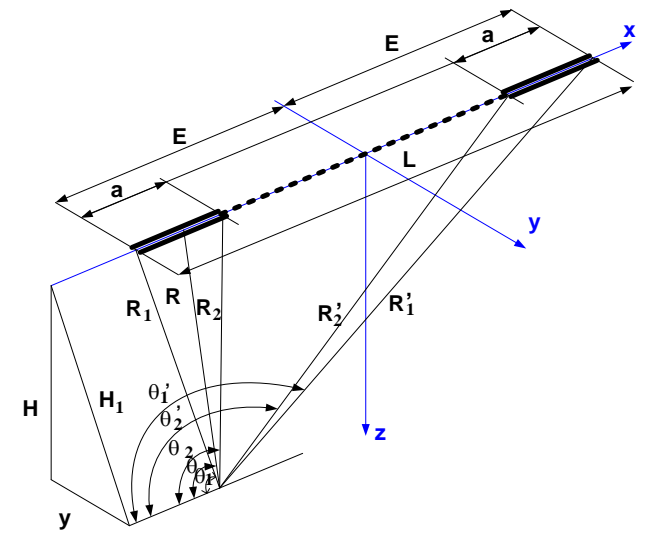

Figure 8. Sources and flows on the ship

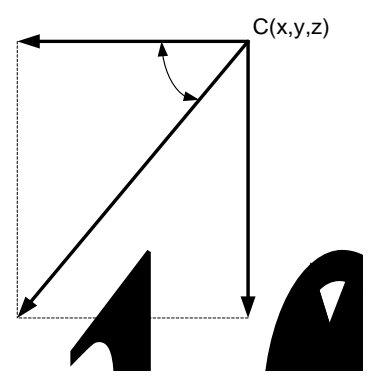

Figure 9. Components of $\Delta \mathrm{w}_{\mathrm{s}}$ velocity in $\mathrm{C}(\mathrm{x}, \mathrm{y}, \mathrm{z})$ point

According with figures 8 and 9, the law which describes the pressure changing below the ship is given by:

$\Delta p_{s}=\frac{\rho v_{0}^{2} S_{M}}{2 \pi a H_{1}}\left(\sin \theta_{2}-\sin \theta_{1}\right)$.

Total pressure is given by:

$\Delta p=\frac{\rho v_{0}^{2} S_{M}}{2 \pi a H_{1}}\left(\sin \theta_{1}-\sin \theta_{2}-\sin \theta_{2}^{\prime}+\sin \theta_{1}^{\prime}\right)$

or $\Delta p=\frac{\rho v_{0}^{2} S_{M}}{2 \pi a} k$,

where:

$k=\frac{1}{H_{1}}\left(\sin \theta_{1}-\sin \theta_{2}-\sin \theta_{2}^{\prime}+\sin \theta_{1}^{\prime}\right)=f(x, y, z)$

Pressure difference below the ship for a source is:

$$
\Delta p_{s}=\frac{\rho v_{0}^{2} S_{M}}{2 \pi a} k_{s}
$$

Pressure difference below the ship for a flow is

$$
\Delta p_{d}=\frac{\rho v_{0}^{2} S_{M}}{2 \pi a} k_{d}
$$

Functions mentioned before could be represented as (figure 10):

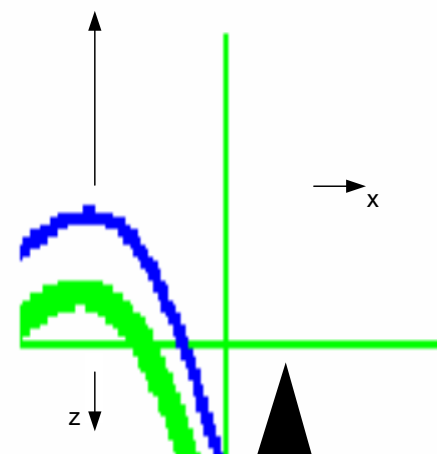

Figure 10 Pressure difference for sources and flows

In figures 11,12 and 13 we have the pressure curves for a ship with dimensions: $L=100 \mathrm{~m}, \mathrm{~B}=17$ $\mathrm{m}$ şi $\mathrm{T}=7 \mathrm{~m}$, which is moving with speed $v_{0}=20$ Knots.

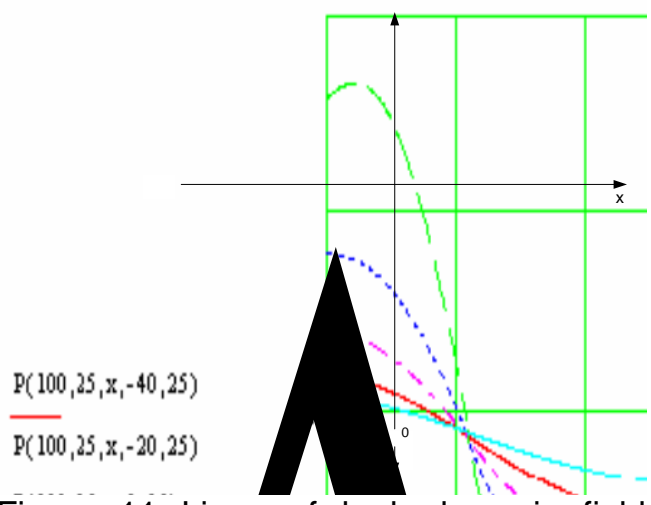

Figure 11 Lines of hydrodynamic field (vertical view)

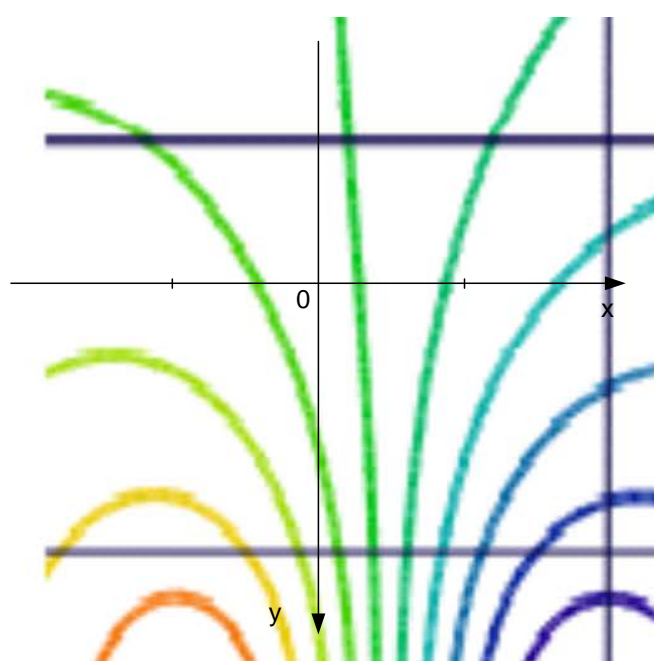
(plan view) 
"Mircea cel Batran" Naval Academy Scientific Bulletin, Volume XX - 2017 - Issue 1

Published by "Mircea cel Batran" Naval Academy Press, Romania /l The journal is indexed in: PROQUEST I

DOAJ / DRJI / JOURNAL INDEX I I2OR / SCIENCE LIBRARY INDEX / Google Scholar / Crossref / Academic Keys I ROAD Open Access / OAJI / Academic Resources / Scientific Indexing Services / SCIPIO / JIFACTOR

Figure 13 Ship's hydrodynamic field

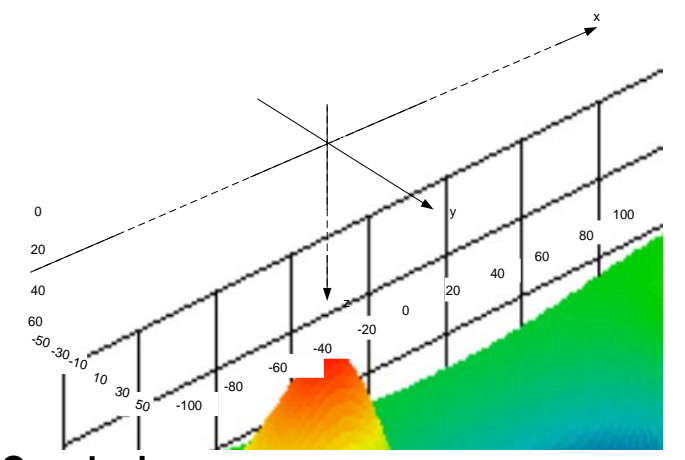

Conclusions

Analyzing the pressure curves around the ship is observed that at relatively large distances by ship, corresponding to depths where marine mines are used, the variations of hydrostatic pressure are important (when a ship is passing), which leads us to conclude that the pressure sensors of the mines will detect ship presence at the mine site. If the mine explosion occurs, the next question is "Which are the effects of the mine explosion on the ship's hull?"

\section{Bibliography}

[1] Barbu, M., Câmpurile fizice ale navelor. Acţiuni şi contraacţiuni, Bucureşti: Editura Militară, 1990. 320pag. ISBN 973-32-00921-1

[2] Bărbărie, Şt., Bazele proiectării minelor marine şi fluviale, Editura Academiei Navale „Mircea Cel Bătrân”, Constanţa, 1994

[3] Chiţac, Vergil, Teoria valurilor şi complemente de hidromecanică navală, Editura Academiei Navale „Mircea Cel Bătrân”, Constanţa, 1999

[4] Clark, C., The Management of Merchant Ship Stability, Trim and Strength, Nautical Institute, Londra, 2002;

[5] Hütte, Manualul inginerului mecanic, Editura Tehnică, Bucureşti, 1995,

[6] Ichimoaei, Ghe., Bărbărie Şt., Tărăbuţă, O., Micu, M., Bazele proiectării bombelor antisubmarin, Editura Academia Navală „Mircea cel Bătrân”, ISBN 978-606-642-003-7, 2011

[7] Ichimoaei, Ghe., Fizica exploziei submarine a minelor, Editura Academia Navală „Mircea cel Bătrân”, ISBN 978-606-642-023-5

[8] Maier V. Mecanica şi construcția navei, Vol. II Dinamica navei, Editura Tehnică, Bucureşti, 1987;

[9] Pricop M., Chiţac V., Oncica V., Teoria şi construcţia navei -Noţiuni teoretice şi probleme, Editura Academiei Navale „Mircea cel Bătrân”, 2009;

[10] Ştefan, Sterie, Mecanica fluidelor, Editura Academiei Tehnice Militare, Bucureşti, 1992

[11] Ştefan, Sterie (coordonator), Paraschiv, T., Codreanu, I., Orban, O., Poradici, P., Mecanica fluidelor. Capitole speciale. Vol.1, Editura Academiei Tehnice Militare, Bucureşti, 1993

[12] Ştefan, Sterie, Ecuaţiile mecanicii fluidelor, Editura Academiei Tehnice Militare, Bucureşti, 1995

[13] Ştefan, S., Nastasescu, V., Malos, G., Lupoiu, C., Ştefan, A., Simularea fenomenelor mecanice si hidraulice, Editura Academiei Tehnice Militare, Bucureşti 2000

[14] Ştefan, S., Avram, E., Paraschiv,T., Poradici, P., Mecanica fluidelor. Capitole speciale, vol. II, Editura AISM, Bucureşti, 1994 